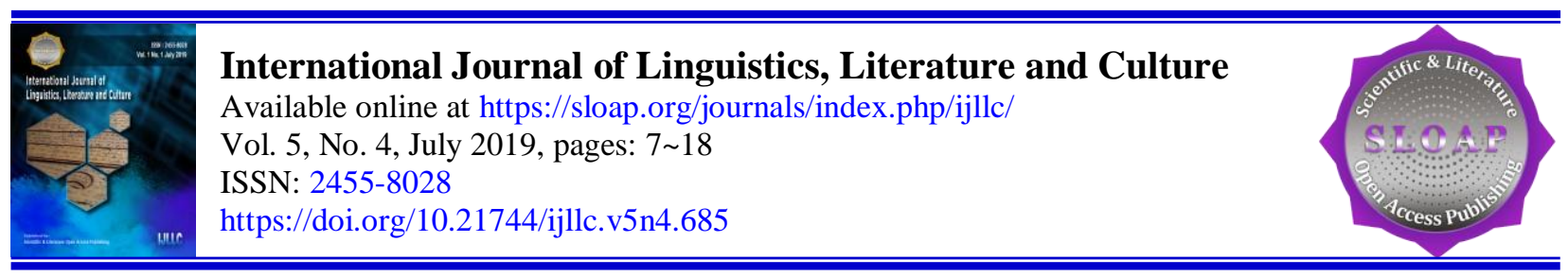

\title{
Achieving Physical and Spiritual Happiness on Bhakti Yoga
}

\section{Article history:}

Received: 18 March 2019

Accepted: 31 May 2019

Published: 31 July 2019

\section{Keywords:}

bhakti yoga;

follower;

ideology;

religion;

spiritual;

\begin{abstract}
The current paper discussed two points of view, namely; first, analyze critically the methods used to internalize bhakti yoga devotion to followers. Second, to critically analyze the implications that have arisen after the establishment of bhakti yoga ideology. These are very interesting to study because practically bhakti yoga provides "convenience" in achieving physical and spiritual happiness. That is, taking a way that does not twist can accelerate to religion destination, namely the achievement of physical and spiritual happiness. The results showed first, the process of understanding bhakti yoga ideology was carried out by (1) through nawa widha bhakti, (2) hermitage, (3) raising cattle, (4) associating with spiritual teachers (sadhu sangga). Second, the ingrained bhakti yoga ideology has implications for religious life, namely the use of symbols of religious sect identity unlike the use of japamala and tilaka. Implications to socio-culture, there is an interaction of follower's culture before and after they take part in bhakti yoga in religious sects. The implication for the economy of religious sects and followers is a capital exchange between followers and capital accumulation on followers and organizations.
\end{abstract}

2455-8028 ${ }^{\circ}$ Copyright 2019. The Author. This is an open-access article under the CC BY-SA license (https://creativecommons.org/licenses/by-sa/4.0/) All rights reserved.

\footnotetext{
Author correspondence:

Artana, I. W.,

Universitas Hindu Indonesia, Denpasar, Indonesia

Tembau, Jl. Sangalangit, Penatih, Denpasar, Bali 80238

Email address: wayan.artana473@gmail.com
}

\footnotetext{
${ }^{a}$ Universitas Hindu Indonesia, Denpasar, Indonesia

${ }^{\mathrm{b}}$ Universitas Hindu Indonesia, Denpasar, Indonesia

${ }^{\mathrm{c}}$ Universitas Hindu Indonesia, Denpasar, Indonesia
} 


\section{Introduction}

Hinduism provides its followers with four ways to achieve happiness. The four ways referred to are known as catur yoga, namely karma yoga, the way of work or service, bhakti yoga, the way of devotion or offerings, jnana yoga, the way of knowledge or understanding the essence of God, and raja yoga through meditation or samadhi. Indonesian Hindu community generally in Bali there are sects such as Shiva Sidanta, Ganapatya, Bhairawa, Sora, Vaishnava, and others. They achieve physical and spiritual happiness generally undergo catur yoga in its entirety. It is carried out in a related way, not separating the way from one another. However, there are sects to achieve physical and spiritual happiness, they prioritize the way of bhakti yoga, namely the way of devotion and offerings.

Their existence has different philosophical understandings will give rise to the pros and cons in Hindu society in Bali towards the way to achieve physical and spiritual happiness. There is a gap between habits (das sollen) and reality in the field (das sein) about how to achieve physical and spiritual happiness for Hindus in Bali. This will cause confusion for the community on achieving religious goals, which if it is not anticipated could result in a religious polarization.

\section{Materials and Methods}

This study was designed using qualitative research by interpreting critically because researchers understand the religious social phenomena related to bhakti yoga ideology as a way of achieving physical and spiritual happiness. Processing and analysis of data are carried out in interpretive critical descriptive frames. Therefore, the conclusion and findings are useful in the socio-cultural life of the community are obtained. Data analysis is carried out simultaneously, starting data collection to get answers to the problem solving, with interactive analysis models from Miles \& Huberman (2002).

Bhakti yoga ideology is understood as first, the belief system and symbolic practices taught by the spiritual teacher to their followers in parampara (aguron-guron). Second, as a justification is a tool of power against all ideas and actions of sect authority. Thus, the ideas and actions of authority can be justified and accepted by followers as truth. Physical and spiritual happiness is a state of feeling (emotion) and/or a happy mind, characterized by pleasure, excitement, satisfaction, pleasure, and intense love.

There are two theories (grand theory) are used as analysis tools of the above problems, namely the structuration of Anthony Giddens to unravel the processes of implanting bhakti yoga ideology and diachronic reception theory as a tool to answer the problems of the implications of the bhakti yoga ideology. They are used with other theories. They are able to analyze other ideologies behind the ideology of bhakti yoga as the main way to achieve physical and spiritual happiness.

\section{Results and Discussions}

\subsection{Implanting Bhakti Yoga Ideology towards Physical and Spiritual Happiness}

Lexically implanting is defined as a process, namely an action, behavior, or understanding a type of belief that is within the scope of a belief system in which someone acts or avoids an action, or about something that is appropriate or inappropriate to do. The process is defined as activities or efforts carried out consciously, planned, and can be accounted for to maintain, train, guide, direct, and increase the knowledge will be practiced in their daily lives (Alwi et al., 2001; Toha, 2000). This study understands the implanting bhakti yoga ideology as an act in certain ways to instill this ideology to followers of religious sects. They are carried out consciously, therefore, it can be implemented in daily life.

Implanting ideology produces a formation of self-identity that gives awareness to believe in all the truths it believes. If someone has had a strong self-awareness of an ideology. It can show his/her identity. Their commitment to the ideology is undoubted. It can be stated that a person's militancy towards his/her ideology begins with the formation of self-identity. It is carried out by the learning process. However, as with other ideologies, the bhakti yoga ideology is not necessarily trusted by its followers as an effort to establish its identity. In this situation, the identity construction of bhakti yoga must be given absolute security or fencing. Thus, the trust can continue smoothly. 
In accordance with the above description of implanting is an interaction between humans that is carried out to produce an action. In the interaction, it is not a pure discourse that plays a role. However, the structure also determines the success or failure of achieving the goals of an interaction process. It should be noted, how the structure gives birth to actions or how the actions series of the actors shape the structure, and how these actions are structured in the daily context (repetitive actions) through the display of the actions of the agents developed (Lubis, 2014).

Structuration cannot be separated from the social development of society. Thus, the understanding is importance the of structure role, allowing a structured action to be developed. Structure and action are interrelated duality, not mutually independent dualism (Wirawan, 2015). This social action is carried out repeatedly, in space and time. Therefore, it shows a pattern that remains valid (Giddens, 2015). Thus, the action remains under the discourse views, which continuously measures what they are doing, how other people are doing, and how things are conducted when they are done (Thomson, 2007).

Unlike implanting of bhakti yoga ideology provides benefits for religious sect authorities. Due to they can monitor the activities of their followers. This monitoring gives confirmation to the authorities as rulers, making the social system of the community unstable, and making followers remain subordinate. There are several ways can be used to inculcate bhakti yoga ideology:

\section{a) Nawa Wida Bhakti}

Nawa wida bhakti is nine forms of devotional consist of (1) srawanam, is a way of devotional by listening to stories about Godhead. 2) smaranam, the way of devotional carried out by chanting. 3) kirtanam, by singing songs that praise the omnipotence of God. 4) arcanam, serving God by using the means of pratima (symbols of God). 5) padasevanam, performed by prostration of devotion before God. 6) dahsyam, the bhakti form by serving sincerely (ngayah). 7) sakhyam, serving God as a friend's relationship (love). 8) vandanam, a way of devotional by thanking God. 9) atmanivadanam, manifestation of devotional by doing serve to God (Riktiasa, 2017). Regarding the nine methods not entirely conducted by the religious community to achieve physical and spiritual happiness. Being parts of nawa wida bhakti are often completed:

\section{1) Smaranam}

Bhakti by chanting is a repetition of the names of God (mantra) continuously. The religious follower's sects in their spiritual lives always train themselves to remember the holy names of God with various manifestations, functions, and all of the omnipotence. Each sect in Hinduism has the freedom to choose the name or manifestation of God in its worship. This is very dependent on discourse and rule that exists in a religious sect. it aims to smooth the way of bhakti yoga as the main way to achieve physical and spiritual happiness. However, the wishes of the group authorities can still be implanted, so that the control of authority over other groups can still be maintained, thereby requiring a value deconstruction, mastery continues (Al-Fayyadl, 2005). It is needed the achievement of physical and spiritual happiness can be achieved faster.

2) Srawanam

It is a form of a devotional by listening to the sacred sayings of God, which are discoursed. It can also be conducted by studying through sacred texts and the omnipotence of God. Learning and understanding the contents of the sacred library by listening to someone who understands and has expressed the contents of the sacred library in his/her entire life. It will make the devotee gain knowledge of devotional from someone who is qualified as a spiritual teacher, as their guide to achieve physical and spiritual happiness through bhakti yoga. Constructing a discourse (speech act) is a reflection of the discourse desires. That is a discourse contains historical elements from the discourse, even though the discourse is not linearly discussed (Giddens, 2015). The discourse occurrence discontinuities are possible because of the discourse role and the structure that works in the discourse formation. In each content discourse, there are discourses desires delivered so that followers experience a change to follow what the discourses want.

Ritzher (2013), it is called a hegemony process which states a power or domination over the life values, norms, or culture of a group of people towards other groups where the group is consciously following the group will which dominates. The group is dominated does not feel oppressed and feels it is a thing that should happen. The sacred literature that is understood textually makes its universal meaning distortion or domestication. Therefore, the contents of the sacred literature will narrow its meaning as a handle or life foundation for other societies. Trusting a source of scriptural truths which is believed to be a

Artana, I. W., Suda, I. K., \& Winaja, I. W. (2019). Achieving physical and spiritual happiness on bhakti yoga. International Journal of Linguistics, Literature and Culture, 5(4), 7-18. https://doi.org/10.21744/ijllc.v5n4.685 
universal revelation of God, the sacred literature should also be interpreted universally (contextually). The universality of God in each creation is very important to be instilled in followers of the sect. Thus, they have a broad understanding and not have a monosemic view that is 'fundamentalist', considers their own true beliefs.

3) Kirtanam

The people in the Hindu tradition in Bali hymns to take part in the yadnya ceremony are called kidung. There are five voices (panca githa) which play a role. The five voices are the sound of kulkul or kentongan in the temple, the sound of gamelan (a traditional Balinese musical instrument), kidung (hymn) from the people who follow the yadnya ceremony, genta (clergy bell), and githa or puja mantra (mantra spoken) by clergy or pemangku. In the holy book Bhagawadghita, the sacred song to worship God is called bhajan, kirtan, or kirtanam means the same as the kidung. It is worshiping God with hymns. Singing God's hymns can be conducted alone or together with other worshipers. It is usually doing kirtanam together there is a devotee who becomes the leader and the others follow. Unlike kirtanam is often named bhajan by the Sai Baba spiritual group (Jendra, 2007). There are also kirtanam performed together with dances, carried out solemnly. Devotees dissolved in songs and dances with an ecstatic devotion (Setia, 2007; Malini et al., 2018; Wirawan, 2018).

The mention of the names of God personifications in kirtanam will make these names stored in memory (mind) in the brain, especially the memory part of the skin of the brain (kortek). The more often the names are spoken, the better the name will be internalized, the belief in the followers of the sect about the truth. The name is increasing, which eventually formed a habitus of the name of the God personification to followers of religious sects (Lubis, 2014; Arismunandar \& Jolasa, 2009). Kamahi (2017) stated that when discourse is built, the discourse is actually controlled, selected, organized, and distributed according to the author because discourse is always constructed according to certain rules (episteme). It defines a discourse truth has a chain with the agent's power that constructs it. Even though there is a powerful element in the mantra selection for kirtanam, it is a way to make bhakti yoga ideology of worship to followers easier. A spiritual teacher is supposed to find the easiest, most important, and in accordance with the development of the yoga so those followers will be easier to understand what they are teaching.

4) Arcanam

The worship of God symbolized in the form of statues (iconism), is one of the cultures of the unknown Sindhu River valley in the Vedic Religion (Phalgunadi, 2013). This habitus will eventually become a daily habit of behavior. There is no single religion or belief that exists in this world that does not worship God through symbols; e.g., using the direction/qibla, sound, light, statues, buildings, pictures, flags/banners. Hindus who worship through various symbols or niyasa/pratika including through statues have the belief that God cadu sakti i.e., Maha Ada, is believed to reside in symbols that have been purified according to the religious tradition sect that $\mathrm{s} / \mathrm{he}$ believes.

For Hindus, the statues are not merely objects/additional means, but are part of the inner mechanism of devotional and belief. God Almighty is everywhere (vyapi vyapaka), permeates all that is (isvara sarva bhutanam) and manifests in each being both movable and immovable (visva virat svarupa), then worshiping God by means of statues is truly useful and awakens God's awareness (Sudarma, 2018). Due to the religious authorities know that society respects these symbols very much as local traditions. They adopted it selectively, thus, the followers would feel the devotional ideology of yoga integrated into the arcanam local culture. Thus, the authorities can easily incorporate their ideology with their followers. It is formulated in packages that have a sense of local culture. That is, the skin is local culture, however, it contains ideology from the authority of religious communities (Nuraeni \& Alfan, 2012; Sukarma, 2016; Gepu, 2018).

The implanting of ideology in this context is more effective. It is conducted by directing the worshiper's views to a structure (read: statues), which has an important position in the spiritual life of the religious community. Bhakti with the worship of God through the statue symbol is intended as a medium of connection and appreciation to God. The religious follower's sects are connected with idol actors in the sacred literature they believe in. Therefore, the integrity and authenticity of a tradition are more important in defining a tradition than the tradition length can survive (Utama, 2015).

On this way, if the devotion to God is very great, surely we will serve and worship God through the statue symbol will become more real and give a very deep spiritual feeling. Thus, the bhakti yoga ideology 
of a religious community will be acceptable to all communities in the Hindu community. The foregoing proves the truth of the premise of the deliberative communication theory Habermas (2002) (consultative communication) which stated the discourse legitimacy is not established from the start, however, is obtained through the rational discourse of the citizens. Practically, if a discourse is legitimate, it needs to carry out public deliberation, which involves all parties including opposing groups, because the discourse legitimacy is also determined by groups outside of them (Menoh, 2018; Watra, 2016; Mishra, 2016).

5) Padasevanam

Padasevanam is a way of devotional in religious sects to always foster an awareness of respecting God creatures. A tradition will bring someone to a truth made by structure, believing that the truth. They will act based on everything that has been structured. The creative power they have is difficult to express. Furthermore, the rationality that will dominate his/her mind, and everything that interferes with the tradition. They will find the basis of rationalization. Making followers of a religious sect is like a machine that works on the orders of others. This situation is required by the religious sect structure that adheres to the parampara system. Thus, it will encourage the encouragement of sect followers to imitate the attitudes and behaviors of the authorities. Therefore, authoritative power can still be maintained and can be maintained.

This is in accordance with O'Neil (2008) stated that the habits that arise are the result of the relationship between the response and the stimulus that continues to occur. A person's behavior does not arise from the spontaneous results of the response given because of a stimulus only, but also there must be impulses from within (drive) that $\mathrm{s} / \mathrm{he}$ did not realize or encouragement that s/he realized that eventually made the individual move.

b) Hermitage

Tapa is meant to control energy so that it is centered. It can be used for a purpose. Hermitage is a lifestyle to stay away from worldly pleasures. The hermitage essence is to look for a new atmosphere to do "selfpurring" by removing negative energy. This is in accordance with Ananda (2015: 30), imprisonment does not have to go to the forest in search of sacred trees. It is not necessary to go to the most sacred temple every night, but enough at home by doing meditation. All temptations are removed first and we become solemn with the spells we like so that we in silence can reach the samadhi stage, true silence. Therefore, the hermitage in question is the self-control of desires, the disturbances that come can be from outside or inside oneself. Thus, the mind can be focused on a certain thing.

Self-control is an asceticism, namely self-denial of all luxuries (read: excessive desires). Asceticism basically in religious sects teaches life to reflect on self-control to get the life perfection towards physical and spiritual happiness. There are four pillars of asceticism that must be conducted if you want to carry out bhakti yoga to achieve physical and spiritual happiness, including: (1) not committing adultery. The aim is to avoid unauthorized sex; (2) Not doing violence to every creature (ahimsa), because every living thing is a train of spirits or atma. Hurting a living being means not giving respect to the spirit or atma in that creature; (3) Not drinking hard, because it will weaken the ability to achieve awareness; (4) Not gambling because it will make the mind difficult to harmonize, control. Gambling makes the mind always nervous. It is stated that asceticism (self-harm) is a self-loathing behavior (hating life) because it does restraints on oneself (Lubis, 2014). The asceticism attitude, even so, is still relevant to be carried out, considering that the achievement of physical and spiritual happiness requires not only trust but more than that which is a belief. If there are strong bases in self, the belief will grow and develop (Baba, 2016).

c) Cattle breeding

O'neil (2008) ideology is seen as first, describing certain general characteristics, nature, society, or both. Second, there is a calculation of the relationship between what is done and what should be done. That is, a formulator tool, ideology does not just tell us about how the world really is, and how we must behave, but it deals with the direction given by one to another. Third, ideology is not only trusted by certain members of social groups, but it is believed in such a way that it at least formulates part of their social existence. Its concepts are embedded in and their beliefs are made conditional by some actions and transaction so that the appearance characterizes their group's social life.

Having seen ideology from Alastair's point of view, it means ideology is not only the formation of ideas are applied to public problems, but also a collection of concepts are used to give direction, ways of thinking, how to do things, to reach goals, someone, understand, theory, which is a program. Therefore, an ideology

\footnotetext{
Artana, I. W., Suda, I. K., \& Winaja, I. W. (2019). Achieving physical and spiritual happiness on bhakti yoga. International Journal of Linguistics, Literature and Culture, 5(4), 7-18. https://doi.org/10.21744/ijllc.v5n4.685
} 
contained an idea of the discourse, the purpose, the way to achieve the goal, even implicitly also can be known by other discourses as connoisseurs of the idea. To be able to implant an ideology in practice, the agent of discourse will first determine what practices will be used to instill the ideology with the agent, meaning that there is a link between agents and structures (Giddens, 2005).

The practice here is an understanding expression has been embedded in the followers of religious sects. The bhakti yoga ideology is a beliefs system and symbolic practices relate to social practices in love, and all results are given to God. In symbolic beliefs and practices this is not limited to humans but also love to other living beings.

Bhakti as symbolic practices in Hinduism is obligatory on four classes of society (catur warna). Brahmins are obliged to worship God and their manifestations with various ceremonial means and learn the Vedas. The knight devotion can be done by giving alms to the brahmana, studying science and the most important thing is to take up arms to protect the motherland. A Vaishya devoted to raising livestock, trade, and agriculture. Shudra is to provide the best possible service (Riktiasa, 2017). Bhakti is intended as an obligation that is carried out based on the professionalism possessed. Carrying out professional activities, obeying all rules in carrying out obligations, undoubtedly what is expected will be realized. Bhakti implementation is not only directed at humanity but also for all living things, which are believed to have something to do with the manifestation of Godhead.

Cattle breeding is no stranger to Balinese people. This activity is mostly carried out as a side between the main work of farming rice. As a side job, most farmers in Bali raise beef cattle for sale. This is different from raising cattle in religious sect communities. It is to keep dairy cows for milk. Seeing in the community especially for Hindus, there is a reluctance to eat beef because they respect cows as mother entity that we have to respect for other entities which mothers who give birth are called biological mothers, mothers who breastfeed even if they do not conceive and give birth, mothers who care and caring even though not giving birth and breastfeeding, and the motherland, namely earth, and nature who have provided livelihoods must be preserved.

Dairy cows raised by religious sects produce milk to be used to fulfill the celebration means. The excess milk production produced is sold to the public in pure milk form every day. Thus, the religious sect community gets the income used to take care of the cows and the other activities continuity. Sects who care for these cows are given adequate rewards. The success of religious sect authority to instill beliefs about the scriptural truths about cattle is an animal that must be respected, making its followers have the belief that the cows must be loved as their form of serving God. Meanwhile, the authorities get capital gains and cheap labor.

The structured doctrine of ideology afflicts followers in their daily lives. Therefore, they are without realizing their actions make them always under the intervention and authorities supervision. The agents who have a lot of knowledge and abilities will be able to intervene with other parties. Thus, they take structured actions in their daily lives, in accordance with the wishes of agents (Thomson, 2007).

Unlike doctrine is needed in an organization to instill a belief on the attitudes and authority behavior. Thus, the purpose of the community of sects and followers in it is to achieve physical and spiritual happiness more easily achieved. However, doctrine narrows the followers understanding (read: monosemy) needs to collaborate more broadly. Therefore, they become more humanistic.

d) Associating with spiritual teachers

Intercourse is a relationship that is intertwined between individuals that involve emotions (feelings), thoughts, behavior, and self-identity that is on it. It is done by individuals with individuals, individuals with groups, and between groups. In social interaction, there is a message conveyed by the discourse. Thus, the audience can understand and want to follow what the discourses want. The association or implanting of ideology by the spiritual teacher is clearly functional for religious sect authority in achieving physical and spiritual happiness. However, on the contrary, the spiritual teacher's interaction as discourses with their followers makes followers very dependent on the parampara system of implanting bhakti yoga ideology. Therefore, they are not ready to develop their own ideas.

The implanting of bhakti yoga ideology by parampara was made standard for the religious sect authorities requiring each follower of the sect to obey it, without exception the spiritual teachers. Thus, a spiritual teacher will convey the truth adheres to and in its implementation is limited to the structure or rules that apply in the sect society. 
Nevertheless agents (read: spiritual teachers) and religious sect structures are needed in the followers effort to get closer to God because agents will guide them using structures as boundaries. Thus, the spiritual teacher will give direction according to the prescribed structure boundaries. All structures in a system are functional against structures and otherwise dysfunctional for other structures (Ritzer, 2013).

\subsection{Implications of bhakti yoga ideology implementation}

The implication is involvement or circumstances involved. It has a relationship with something. Implications are also interpreted as the consequences and consequences caused by the implementation of a particular policy or activity. Implications can be interpreted as an impact. It is felt when doing something or an effect. It is caused in the future after doing something. Marheni et al., (2018) interpret the implications as changes that will occur if something that has been understood is applied in life. This implication does not stop at one effect but can chain from one implication to the next implication. However, the implications do not just happen, the implication is a process that is preceded by a reception about something. A reception will be accompanied by an interpretation, and even a very detailed interpretation (Ratna, 2012).

If the conception of receptions, implications, and bhakti yoga ideology are associated, then an understanding can be constructed that the implications will occur preceded by the acceptance of bhakti yoga ideology by followers of religious sects, then applied in daily life, giving rise to implications on the dimensions of the sect followers:

a) Implications for religious life

Durkheim (1961) opinion that religion is as a set of beliefs and practices are related to the sacred and which create social ties between individuals (profane). Thus, the direction of religious practices tends to split in two, one part to ascetic control while the other to the indulgence of orgiastic desire. Asceticism is a lifestyle characterized behavior or abstinence from worldly pleasures, which are often conducted to achieve spiritual purposes. Orgiastic behavior will continue to do this over and over again until the pleasures of the world become addictive to him/her (Turner \& Bryan, 2006).

Related to Durkheim above opinion, in religion contained spiritual and religious elements. According to Hill et al., (2009) with religious people can also obtain identity, sense of belonging, meaning, health, or physical and spiritual happiness through their involvement in religious sects. The religious has methods, practices of worship taught by religious sects. Thus, the practice of devotional yoga practices carried out will bring psychological benefits to the individual, if it is done with a devotion directed to the Holy God. The spiritual is a way of being and experiencing that arises because of an awareness of the transcendent dimension and is characterized certain values that appear, both in oneself, others, nature, life, and whatever is considered 'ultimate'. It makes a person feel a longing and a strong urge to understand various things in life, can be related to religion or others (Zinnbauer et al., 1997 in Amir \& Lesmawati, 2016).

As an ideology that will bring followers towards physical and spiritual happiness. Bhakti yoga will be maintained and implanted deeper (read: detribalization). The spiritual teacher communication with his followers is needed. Communication is the delivery of information and giving meaning and reaction to the symbols (read: information) delivered. They move based on the meaning given to the symbols used in social interaction (Nurhadi, 2017).

Freedom to create symbols with certain values and create symbols for other symbols is important in symbolic processes (Hayakawa, in Mulyana \& Rahmat, 2006). These social symbols can manifest in the form of physical objects (tangible objects), words (to represent physical objects, feelings, ideas, and values), and actions (which people do to give meaning in communicating with others). It is closely related to the activities of human life with religious symbols of bhakti yoga ideology because indeed human life is one of them in a symbolic environment.

The implementation of bhakti yoga ideology turned out to make the followers religious, having seen from the symbols they used reflected as a follower of a religious sect unlike the use of tilaka, japamala, and so on. Its critical conception is interpreted as a tool to direct behavior in accordance with the goals of the ideological discourse. An ideology also means of justifying what is planned, ideological makers. Thus, someone will be able to instill bhakti yoga ideology according to the will of the maker in achieving physical and spiritual happiness, which is certainly beneficial for the ideology-making authority.

Artana, I. W., Suda, I. K., \& Winaja, I. W. (2019). Achieving physical and spiritual happiness on bhakti yoga. International Journal of Linguistics, Literature and Culture, 5(4), 7-18. https://doi.org/10.21744/ijllc.v5n4.685 
b) Implications for socio-cultural life

The religious sect individuals are individual beings and social beings who want to always socialize, then the interaction between them and other parties is relationships are arranged or formed from the realization of the actor role (role play) works dynamically. Their existence in the sect community will be bound a form of social unity as a result of the same understanding of religious life, similarities in spiritual teachers, and others. As a unit within the social jurisdiction, sects usually have a certain identity or cultural characteristics as their community personality. It is a sociocultural change occurs in society.

This change can be stated as one of the modus of a religious sect to survive or defend itself. It becomes sustainable. Therefore, religious sect communities are never static, always dynamically changing from one state to another. They try to present the ideological structure of bhakti yoga into the culture which they are located. The difference from one condition to a different condition that occurs in society is a change measure, both changes in structure and culture. These aspects are the targets for change because these two aspects are elements that form a system in a religious sect (Sulasman \& Gumilar, 2013). The followers as the majority group embraced the bhakti yoga ideology by a minority group of sect community rulers. This can happen because the minority group has religious ability and ascetic worship. It has been qualified.

The most religious traditions lay people are often considered second-class citizens because they lack the ability, training, and magical power or charismatic authority such as religious sect authority. The superior status of the authorities will strengthen their grip on their followers. This situation is consistent with Turner \& Bryan (2006) the masses are forced to depend on the religious aristocracy which develops its own religious competence, regardless of whether the mass is included or not. In any religion that is based on 'systematic reward procedures', people will find the fact that 'rebirth' is religiously limited to certain groups of people.

The integration of the two habits before and after following the teachings of bhakti yoga in the followers of religious sects, made possible the acculturation between the two habits. This acculturation can be in the form of how to dress in religious activities or the combination of ways to make offerings to God. The followers of religious sects in achieving physical and spiritual happiness, combining religious rituals in their social life. The ceremony activities are still being carried out but the materials, especially the ingredients of the animals are removed. The ceremonies of followers of bhakti yoga in the community still follow the culture. They are located. The reduction in the contents of upakara in the form not using meat or ingredients from animals is a way to strengthen the four pillars form the basis of the bhakti yoga ideology as mentioned above.

A person's acceptance being a student by a spiritual teacher does not just happen. As explained above, there are certain steps that must be followed and passed until they are accepted as students. In the early stages of restraint on food, gambling, sexual intercourse, and liquor are things that must be done. This requirement will continue to be carried out even though they have achieved the highest level of spirituality (sannyasin) because ascetic behavior is a method for self-discipline.

The methods allow strict control of the body use, which always points to its strength and attaches it to reasons to be obeyed, are used, can be called 'disciplines'. The religious sect the followers have been embraced by the bhakti yoga ideology. They do not have the freedom to interpret what they hear or see. Abdullah \& Udasmoro (2009) the society dynamics reflected a structuring structure and structure especially in religious life religious sects cannot be implemented.

The confusion in the bhakti yoga ideology for the sect occurs because bhakti yoga understanding is performed in parampara. However, this system makes the interaction of spiritual teachers with their followers better, more familiar, such as the relationship between parents guiding their children, because the relationship between them is very close. Unlike the worshipers easily absorb the advice and behavior of spiritual teachers who are certainly 'suitable' with the authority of the religious sect.

c) Implications for economic life

The sect followers have given up their time to study and understand the bhakti yoga ideology from the authorities to fulfill their desires to achieve physical and spiritual happiness. They identify themselves with that ideology. The internalization of the bhakti yoga ideology has implications for economic life, which is all efforts and human power in fulfilling their life needs in order to achieve a prosperity level. Thus, economics which is one aspect of the follower's lives is also affected activities to deepen bhakti yoga as a way to happiness.

This economic aspect results in transactions between one individual and another with the meeting aim for the food needs, clothing, or shelter through the number exchange capital. The way to meet those needs can be 
done utilizing the resources (capital) they have. The followers who come from various professions i.e., doctors, teachers, contractors, architecture, and other non-formal professions e.g., woodcutter, builder, carpenters, traders, etc. each need a fee for their lives. They can also form networks among followers to promote their business.

Their participation follows the teachings of bhakti yoga as a way to happiness, followed by the search for material capital among fellow followers on the sect community. This situation proves Derrida's deconstruction theory which stated there is another meaning or purpose in a discourse that arises depending on the audience interpretation (Al-Fayyadl, 2005). Every human being to survive, they must use the optimal capital available to him. The capital exchange with other parties can not be avoided to meet the needs of life, thus, it is good to use of capita. It can support the achievement of physical and spiritual happiness.

\subsection{Research Findings}

Several research findings can be formulated, they are factual findings and theoretical findings:

a) Factual findings

1) The asymmetry existence of knowledge about God between the religious sect authority and its followers.

2) The asymmetry gives rise to an authority over followers, which is carried out parampara namely, structured starting from instilling the scriptural truths of the sacred library, culturing to actors in the holy library as God, and instilling an understanding the spiritual teacher is representative of the cultured actor.

3) The followers who have been ideologically controlled will carry out all authority orders on it without daring to oppose it and regard it as an obligation that must be carried out.

4) The capital exchanges occurrence between followers or religious sect communities with followers. Thus, there is an increase in the quantity of capital (read; material) both in the followers or community of the sect concerned.

b) Theoretical findings

1) Postmodern assumptions have a characteristic of fragmentation (fragmented into smaller), indeterminacy, and a mistrust of all things that are universal (worldview) fall apart when viewed from the parampara system which is used to instill bhakti yoga ideology.

2) Marx theory of the class differences formation (social level) in a society based on the mastery of the means of the production (economic) fall. In religious sect communities, social stratification is formed because of the capital asymmetry of spiritual and religious knowledge about devotion to God.

3) Strengthening Derrida's deconstruction theory of Gramcy's deferred meaning and hegemony theory. The implanting of bhakti yoga ideology to serve and offer something to God. It is a way of religious sect authority to strengthen its dominance to followers, and followers feel obliged to do so as a manifestation of their devotion to God. Thus, the authority has full authority to regulate the followers in the sect community interests.

\section{Conclusion}

First, the implanting process of bhakti yoga ideology is carried out through (1) nawa widha bhakti, (2) hermitage, (3) raising cattle, (4) associating with spiritual teachers (sangga sadhu). Secondly, the implanting of bhakti yoga ideology has implications for religious life, namely the use of religious symbols sect identity unlike the use of japamala and tilaka. Implications to socio-culture, there is an interaction of follower's culture before and after they take part in bhakti yoga in religious sects. The implication for the economy of religious sects and followers is that there is a capital exchange between followers and the capital accumulation on followers and organizations.

\section{Suggestions}

a) It is suggested to the next researcher who wants to explore the bhakti yoga ideology, to conduct research on several religious sect communities. Therefore, they can get comparable research results.

b) To followers of religious sects, it is recommended to carry out the bhakti yoga ideology with more recognition for other people. Therefore, the achievement of physical and spiritual happiness is faster.

Artana, I. W., Suda, I. K., \& Winaja, I. W. (2019). Achieving physical and spiritual happiness on bhakti yoga. International Journal of Linguistics, Literature and Culture, 5(4), 7-18. https://doi.org/10.21744/ijllc.v5n4.685 
c) It is recommended to health academics to research and use social-religious knowledge in understanding the disease causes. Thus, disease prevention can be conducted with the socio-cultural approach of the community concerned.

d) The religious management sect communities are expected to provide a broader and acceptable interpretation of the bhakti yoga ideology of cultural life that has grown and developed in Bali. Thus, it will further enrich the Balinese culture.

e) Hindu religious institutions should encourage cultural acculturation insects within the Hindu community, thus, creating diversity in a Hindu unity that is stronger in social, economic, cultural, and symbolic capital.

Conflict of interest statement and funding sources

The authors declared that they have no competing interest.

Statement of authorship

The authors have a responsibility for the conception and design of the study. The authors have approved the final article.

Acknowledgments

The authors would like to thank the editor team of IJLLC for their valuable time, support, and advice in completing the current article. 
References

Abdullah, I., Wening, U., \& Hasse, J. (2009). Dinamika Masyarakat dan Kebudayaan Kontemporer. Yogyakarta: Tici Publications Bekerjasama Pustaka Pelajar.

Al-Fayyadl, M. (2005). Derrida. LKIS Pelangi Aksara.

Alwi, Hasan. (2001). Kamus besar bahasa Indonesia. Balai Pustaka.

Amir, Y., \& Lesmawati, D. R. (2016). Religiusitas dan Spiritualitas: Konsep yang Sama atau Berbeda?. Jurnal ilmiah penelitian psikologi: kajian empiris \& non-empiris, 2(2), 67-73.

Ananda, Prema. (2015). Luangkan Waktu Untuk Bertapa. Retrieved from https://www.facebook.com/mpujayaprema/posts/

Arismunandar \& Jolasa. (2009). Pierre Bourdieu dan Pemikirannya tentang Habitus, Doxa dan Kekerasan Simbolik. Retrieved from https://www.academia.edu/ 4915862/

Baba, BSS. (2016). Intisari Bhagawad Gita. Surabaya: Penerbit Paramita.

Chabib, T. (1996). Kapita Selekta Pendidikan Islam. Yogyakarta: Pustaka Pelajar.

Deddy, M., \& Rakhmat, J. (2006). Komunikasi Antar Budaya Panduan Berkomunikasi Dengan Orang-orang Berbeda Budaya. Bandung: PT. Remaja Rosdakarya.

Durkheim, E., König, R., \& König, R. (1961). Die Regeln der soziologischen Methode (Vol. 3). H. Luchterhand.

Gepu, W., Suda, I. K., \& Suyasa, I. M. (2018). Religious conversion towards Hindu Kaharingan to Christianity. International Journal of Linguistics, Literature and Culture, 4(4), 25-37. https://doi.org/10.21744/ijllc.v4n4.257

Giddens, A. (2005). Konsekuensi-Konsekuensi Modernitas. Yogyakarta: Kreasi Wacana.

Habermas, J., Illuminati, A., Masini, F., \& Perretta, W. (2002). Storia e critica dell'opinione pubblica (hlm. 49). Laterza

Hood Jr, R. W., Hill, P. C., \& Spilka, B. (2018). The psychology of religion: An empirical approach. Guilford Publications.

Huberman, M., \& Miles, M. B. (2002). The qualitative researcher's companion. Sage.

Jendra, I. W. (2007). Sampradaya: kelompok belajar Weda, aliran dalam agama Hindu dan budaya Bali. Panakom Pub..

Kamahi, U. (2017). Teori kekuasaan michael foucault: tantangan bagi sosiologi politik. Jurnal Al-Khitabah, 3(3).

Lubis, A. Y. (2014). Postmodernisme: teori dan metode. Jakarta: Rajawali Pers.

Malini, K. H., Yasa, I. W. S., \& Utama, I. W. B. (2018). Yoga as lifestyle of postmodern society in Bintaro Jaya. International Journal of Social Sciences and Humanities, 2(2), 1-14. https://doi.org/10.29332/ijssh.v2n2.112

Marheni, A.A.I.N, Dantes, N., Astaw, I. B. M. (2018). Bahan Ajar Pekerti (Pelatihan Keterampilan Dasar Teknik Instruksional). Jakarta: PT. Raja Grafindo Persada.

Menoh, G. A. (2015). Agama Dalam Ruang Publik: Hubungan Antara Agama dan Negara dalam Masyarakat Postsekuler Menurut Jurgen Habermas. Kanisius, Yogyakarta.

Mishra, S. K. (2016). The paradigm of religious evolution:the transformation of rudra to pashupata. International Journal of Linguistics, Literature and Culture, 2(3), 28-34.

Nuraeni, H. G., \& Alfan, M. (2013). Studi budaya di Indonesia. Pustaka Setia.

Nurhadi, Z. F. (2017). Teori Komunikasi Kontemporer. Prenada Media.

O’nell, W. (2008). Ideologi-idealogi Pendidikian. Yogyakarta: Pustaka Pelajar.

Phalgunadi, I. G. P. (1993). 14.5 Versions, translations, and derivative works. Mahabharata, 2, 87.

Ratna, I. N. K. (2004). Teori, metode \& teknik penelitan sastra: dari strukturalisme hingga postrukturalisme: perspektif wacana naratif. Pustaka Pelajar.

Ritiaksa, I. W. (2017). Internalisasi Ajaran Bhakti Pada Pembelajaran Agama Hindu Di Sekolah Dasar Negeri 27 Pemecutan, Kecamatan denpasar barat, Kota Denpasar. Disertasi (unpublished). Denpasar: Program Doktor Ilmu Agama dan Kebudayaan Program Pascasarjana Univ. Hindu Indonesia.

Ritzer, G. (2004). Teori Sosial Postmodern. Terjemahan Muhammad Taufik.

Ritzer, G. (2014). Sosiologi Ilmu Pengetahuan Berparadigma Ganda, Jakarta: PT. Raja Grafindo Persada.

Setia, Putu. 2001. Hare Krishna Selayang Pandang. Dalam "Catatan dari Mahasabha VIII". https://dharmasastra3.wordpress.com

Sudarma, W. (2018). Memuja Tuhan Melalui Arca (Archanam Sarva Pujanam). https://dharmavada.wordpress.com

Sukarma, I. W. (2016). Tri Hita Karana theoretical basic of moral Hindu. International Journal of Linguistics, Literature and Culture, 2(3), 102-116.

Artana, I. W., Suda, I. K., \& Winaja, I. W. (2019). Achieving physical and spiritual happiness on bhakti yoga. International Journal of Linguistics, Literature and Culture, 5(4), 7-18. https://doi.org/10.21744/ijllc.v5n4.685 
Sulasman, H., \& Gumilar, S. (2013). Teori-teori kebudayaan dari teori hingga aplikasi. Bandung: Pustaka Setia.

Thomson, B. J. (2007). Analisis Ideologi Kritik Wacana Ideologi-Ideologi Dunia. (Penerjemah Haqqul Yaqin). Yogyakarta: IRCiSoD.

Turner, B. S. (2006). Vulnerability and human rights (Vol. 1). Penn State Press.

Turner, B. S., \& Muzir, I. R. (2006). Agama \& teori sosial. IRCiSoD.

Utama, B., \& Wayan, I. (2015). Air, Ritual dan Tantrisme di Bali dalam Revitalisasi Agama Tirtha di Bali (A. Paramita, ed). Denpasar: Fakultas Agama, Pascasarjana Unhi.

Watra, I. W. (2016). The hindus belief of catur brata penyepian in bali. International Journal of Linguistics, Literature and Culture, 2(2), 112-125.

Wirawan, D. I. (2012). Teori-teori Sosial dalam Tiga Paradigma: fakta sosial, definisi sosial, dan perilaku sosial. Kencana.

Wirawan, I. G. B. (2018). Surya Namaskara benefits for physical health. International Journal of Social Sciences and Humanities, 2(1), 43-55. https://doi.org/10.29332/ijssh.v2n1.78

Zinnbauer, B. J., Pargament, K. I., Cole, B., Rye, M. S., Butfer, E. M., Belavich, T. G., ... \& Kadar, J. L. (2015). Religion and spirituality: Unfuzzying the fuzzy. In Sociology of religion (pp. 29-34). Routledge.

\section{Biography of Authors}

\begin{tabular}{|l|l||} 
dr. I Wayan Artana, SH., M. Biomed was born in Badung on January 12, 1966. The \\
professional education was finished in the Faculty of Medical, Udayana University. \\
The Master degree was completed on Biomedics Postgraduate Program, Udayana \\
University. He currently is completing a Doctoral Program on Religion and Culture in \\
Universitas Hindu Indonesia. \\
Email: wayan.artana473@ @mail.com
\end{tabular} \mid $\begin{aligned} & \text { Prof. Dr. I Ketut Suda, M.Si. was born in Tegallalang, December 31st, 1962. He is } \\
& \text { a professor in the field study of the education sociology. He teaches at the University of } \\
& \text { Hindu Indonesia, Postgraduate Program, UNHI Denpasar. He graduated his } \\
& \text { bachelor degree in the Pancasila and Citizenship Education Studies Program, FKIP } \\
& \text { UNUD in Singaraja. He completed his Master and Ph.D. degree in the Cultural } \\
& \text { Studies Program, Udayana University in Denpasar. } \\
& \text { Email: suda.unhidps@yahoo.co.id }\end{aligned}$

